\section{SOI: $1.1 /$ TAS DOI: $10.15863 /$ TAS International Scientific Journal Theoretical \& Applied Science}

\author{
p-ISSN: 2308-4944 (print) e-ISSN: 2409-0085 (online)
}

Year: 2017 Issue: 09 Volume: 53

Published: $30.09 .2017 \quad \underline{\text { http://T-Science.org }}$
Azamat Khaydarovich Khaydarov

$\mathrm{PhD}$,

Director of Scientific methodic Center of organizing the activity of Republican cultural organizations Tashkent, Uzbekistan

SECTION 18. Culturology.

\title{
AN EXPRESSION OF SPIRITUAL COURAGE
}

Abstract: The spiritual, moral and spiritual heritage of the President of the Republic of Uzbekistan in the years of independence, the rise, revival, development and progress of our nation's centuries-old culture, art and culture, as well as radical reforms in the field of culture and arts are highlighted in the article.

Key words: Independence, transition, reform, decision, state program, institution, deaf, culture, art, patriotism.

Language: English

Citation: Khaydarov AK (2017) AN EXPRESSION OF SPIRITUAL COURAGE. ISJ Theoretical \& Applied Science, 09 (53): 212-215.

Soi: http://s-o-i.org/1.1/TAS-09-53-32 Doi: crossef https://dx.doi.org/10.15863/TAS.2017.09.53.32

\section{Introduction}

During the first years of independence, the first President of our Republic, Islam Karimov, emphasized the importance of spirituality, culture and art in the formation, development and advancement of the state of Uzbekistan, and said: "During the transition to market economy, culture, art and literature were in difficult situation. The President should take on his shoulders to save them from the economic shock", "It is a sin to forget spirituality because of market economy. No one needs this kind of society if we chase after good money and profit, but if our people are spiritually poor", "We must always support the creators of our souls, writers, poets, artists, folk talents and talented youth. We must pay for it", "The pursuit of good intentions, first of all, links with to all of us, we must solve a great problem, which is more than all else, must go out a spiritual crisis. This is one of the most honorable and most difficult tasks" [4, p. 195]. At the beginning of such difficult, but honorable and magnificent works, the head of state directly supported the creativity of the creative people.

\section{Materials and Methods}

The years of independence became the years of national spirituality, revival of the culture of the Uzbek people. For over the past period, the opportunities for the rise of our values, culture and art have widened. We all are witnessing that the people of the world can see and recognize our achievements in today's socio-cultural and spiritual and educational spheres. It is well-known that in carrying out transitional reforms, special attention was paid to the main factors reflecting the historical, cultural, national and spiritual values of the Uzbek state, namely, the mentality of the nation.

The Communist regime introduced its violent policy and trampled our national culture and art in various ways, with various ideas directed against the spirit of our people. The cultural sites were redirected to serve the Soviet ideology, which was considered to be the so-called "red angles" at that time. Thanks to independence only many opportunities are created to use rich history and rich culture of the Uzbek people under the leadership of the First President of the Republic of Uzbekistan, Islam Karimov.

Thanks to independence, new and historically radical reforms have been launched in culture and arts as well as in all spheres of life of the Uzbek people. The problems accumulated in the field, such as the management of the sphere of culture and art, the formation of a system of training and development of qualified cadres, strengthening the material and technical basis of educational institutions for the sphere of culture and art, professional theaters and other branches of the industry, in the transition period, social protection of the artists and artists of the concert organizations, professors and teachers of the creative staff training institutions and concert makers the need to create a system was one of the most important tasks in the development of our national culture and arts. Indeed, the our President Islam Karimov emphasized that 
these tasks were one of the most important factors of the independent development of Uzbekistan, "The spirituality and culture of the people, reorganizing their true history and their originality have solvable, if we explain notable importance on the successfully renewal and development of our society" [2, p. 121], said our President in his book "Uzbekistan on the path to deepening economic reforms".

Therefore, in the years of independence, more than 30 decrees and resolutions were adopted for the development of the sphere of culture and art. In particular, such as decrees the "On organization of the "Uzbek theatre" ("Uzbekteatr") creativeproduction association", "On organization of the tour-concert association "Uzbeknavo"”, "On further development of art of singing art", "On cardinal improvement and perfection of museums' activity", "On the State program for strengthening the materialtechnical base of children's music and art schools and their further improvement in 2009-2014", "On approval of the State Program for 2010-2020 on protection, preservation, promotion and use of objects of heritage", "On approval of the Program of measures for strengthening of material and technical base and further improvement of their activity in parks in 2011-2015", "On measures establish modern cultural and recreation centers for 2013-2018". These documents serve as one of the important legal basis on the development of culture, art, also, spirituality of our people.

Let's see the decree "On measures establish modern cultural and recreation centers for 20132018" with number 178 of The Cabinet of Ministry, which is one of the decrees related to development of the field. The main purpose of it, is to study and propagandize the traditions of our national culture, to enrich the spiritual world of the population, especially in the rural areas, to create the conditions for their leisure time, and to diversify their favorite arts and art amateur arts to provide them with the opportunity to dance and demonstrate their talent, to organize high quality cultural services to our compatriots living in remote areas. In order to do the tasks fixed in the decree of the Ministry of Culture and Sports, there were created 894 modern cultural and leisure centers on the basis of 1,777 cultural houses and club establishments, which were previously functioning, and today, under the state program, capital repair of these centers and their material and technical base completely upgraded. In addition, Culture and recreation centers with up to 10 new modern buildings will be built in the future until the end of 2018.

Spiritually-educational institutions play a special role in society. In particular, it serves as one of the main propaganda centers for public awareness of economic, social and political reforms in the country. What is the reason why the head of the state paid great attention to the activities of spiritual and educational institutions? This is because spiritual enlightenment institutions are primarily human factors. It shapes his spirituality. Another important feature is that at the same time there is a possibility to work with the population aged 7 to 70 years.

These days "Repair works have been completed and commissioned in about 190 centers. There are 1,062 different clubs, studios and artistic amateur teams. As the centers are equipped with comfortable rooms, necessary instruments, modern furniture and other necessary equipment, the number of participants of the folk art collectives and amateur circles has increased by about 4 thousand people compared to previous years. The paid circles can reach 133 in 2015 and the number of participants is 870 , which has increased by 287 units to 154 in 2016, and the number of participants reached 2140 . This is 1270 more than last year" [15]. These peculiarities are a vivid example of our effective use of artistic creativity in their cultivation in the cultivation of young people at cultural centers. In order to study and promote the creativity of the masterpieces of Uzbek national musical art, respect the rich spiritual heritage, search for and encourage young talent, "When the Elderly People sing" ("Keksalar kuylaganda") literal-artistic concerts, folk-ensembles, singing and dancing ensembles, and festivals "Nurli navolar" of folklore-ethnographic groups which are devoted to the national artists of Uzbekistan, Komiljon Otaniyazov, Tavakkal Kadyrov and national singers of Uzbekistan Mahmudjon Uzokov, Eson Lutfullaev, Orifkhon Hotamov, has been helding in the cultural and leisure centers of Uzbekistan.

Nowadays, at the Ministry of Culture and Sports of the Republic of Uzbekistan, the Ministry of Culture and Sports of the Republic of Karakalpakstan, the Department of Culture and Sports of the regions and the city of Tashkent, the Republican Scientific-Methodical Center for Folk Art and Cultural and Educational Work, and 13 Regional People's Art and Cultural-Educational scientific and methodological centers, 37 professional theaters, 894 cultural and leisure centers, about 70 folk theaters with their "The people" and "The exemplary" titles, 60 more than 3000 folklore groups, 128 ensembles of folk and dance ensembles, 28 vocal-instrumental folk ensembles, more than 3 thousand amateur circles, 225 artworks reconstructed under the Resolution of the Cabinet of Ministers №332 of December 29, 2010 and amusement parks, about 200 towns, departments of culture and sports, and many other cultural and artistic institutions have been working. That is to say, each of them must have the leaders of the first, middle and lower subdivisions, and at the same time, managers, who are responsible for the management, development and perspective of the cultural and art area, one of the major social sectors 
of the country. In order to further improve the issues of elimination of shortcomings and problems in this area, further training of specialists in the sphere of culture and art, at the initiative of the head of our state, in the Institute of Culture and Arts of Uzbekistan, established in 2012, , culture and art managers, as well as the most sensitive aspects of management, culture and arts which requires a definition to the specific features and characteristics of other countries based on the theoretical and practical sources of future management, in order to educate specialists in new specialty "Management of culture and arts" has been launched.

\section{Conclusion}

When the human appears, he strives to knowledge and enlightenment. Hence, culture has come to the attention of rulers, scientists, and progressive intellectuals. It is well known from the history that Sahibkiran Amir Temur is one of the rulers who have greatly contributed to the development of culture, which is an important factor in the formation of our national statehood. At the very moment, we have just been briefed about some aspects of the great care is shown to the culture and art by our first President, Islam Karimov, when Uzbekistan became independent.

From the quotations given at the beginning of our speech, it is clear that despite the many difficulties and problems facing the young state of Uzbekistan, such as pushing, developing, changing the minds of the people, introducing the Uzbek people to the world and confronting them with the great moral vigil of our first President, Islam Karimov, the centuries-old culture, art and spirituality of our people have been preserved. Not only was it preserved, rebuilt, improved, developed and elevated. As a natural pride of national pride, the concept of heroism is formed. Heroism and heroes are always needed. Through them, society's progress will accelerate. Heroism - is an example of exhortation in the training of patriotism. The hero of the nation - the pride and national pride of our nation, the only one and sacred for us - the prosperity of our independent Uzbekistan, for the sake of prosperity of our free and prosperous country, are the heroes of life, life and death. Our culture, our art, as well as the true activist and defender of our national interests, our first President, Islam Karimov is a vivid example of spiritual courage for all creators of culture and art. Our nation, the honor of our people, the feeling of pride with our greatest and majestic national pride should always encourage us to do creative work.

The sudden death of our President has shaken our hearts. However, the faithful successors, who have been honored by the centuries-long commitment of our people, who have trained the great way that he has guided and who are loyal to the leader, the people and his holy land, continue to be one-to-one. The elderly leaders, who have high will and courage, bring the value of Uzbekistan to higher altitudes.

The sense of love and devotion to our motherland, which has inherited from the great spiritual courage owner, will be a true faith for our children, our present and future generations.

\section{References:}

1. Karimov I.A. (1992) “O'zbekistonning o'z istiqlol va taraqqiyot yo'li”. -T.: O'zbekiston.

2. Karimov I.A. (1995) "O'zbekiston iqtisodiy islohotlarni chuqurlashtirish yo"lida". -T.: O‘zbekiston, 1995.

3. Karimov I.A. (1995) "O`zbekistonning siyosiy, ijtimoiy va iqtisodiy istiqbolining asosiy tamoyillari”. -T.: O‘zbekiston, 1995.

4. Karimov I.A. (1996) "O`zbekiston: milliy istiqlol, iqtisod, siyosat, mafkura”. -T.: O‘zbekiston, 1996.

5. Karimov I.A. (1997) "YAngicha fikrlash va ishlash-davr talabi”. -T.: O‘zbekiston, 1997.

6. Prezidentimiz I.A. (1997) Karimovning O'zbekiston Respublikasi Oliy Majlisining 9 sessiyasidagi (1997 yil 29 avgust) so‘zlagan nutqi.
7. Karimov I.A. (1998) “Ma'naviy yuksalish yo'lida"-T.: O'zbekiston, 1998.

8. I.A.Karimov (1999) "Barkamol avlod O'zbekiston taraqqiyotining poydevori" "SHarq"nashriyoti - matbaa konserni. 1999.

9. Karimov I.A. (2002) O'zbekistonda demokratik o'zgarishlarni yanada chuqurlashtirish va fuqarolik jamiyati asoslarini shakllantirishning asosiy yo"nalishlari. "Xalq so'zi”'gazetsi, 2002 yil 30 avgust

10. I.A.Karimov (2003) "Biz tanlagan yo'1 demokratik taraqqiyot va ma'rifiy dunyo bilan hamkorlik yo 'li” T.11. -T.: O‘zbekiston, 2003.

11. Karimov I.A. (2009) "Jahon moliyaviyiqtisodiy inqirozi, O'zbekiston sharoitida uni barataraf etishning yo 'llari va choralari”. -T.: O'zbekiston, 2009. 


\begin{tabular}{l|lrl|l|ll} 
& ISRA (India) & $=\mathbf{1 . 3 4 4}$ & SIS (USA) & $=\mathbf{0 . 9 1 2}$ & ICV (Poland) & $=\mathbf{6 . 6 3 0}$ \\
Impact Factor: & ISI (Dubai, UAE) $=\mathbf{0 . 8 2 9}$ & PUHL (Russia) $=\mathbf{0 . 2 0 7}$ & PIF (India) & $=\mathbf{1 . 9 4 0}$ \\
& GIF (Australia) & $\mathbf{0 . 5 6 4}$ & ESJI (KZ) & $=3.860$ & IBI (India) & $=\mathbf{4 . 2 6 0}$ \\
& JIF & $\mathbf{1 . 5 0 0}$ & SJIF (Morocco) & $=\mathbf{2 . 0 3 1}$ & & \\
\hline
\end{tabular}

12. Karimov I.A. (2008) "YUksak ma'naviyatengilmas kuch". -T.: Ma'naviyat, 2008.

13. Karimov I.A. (2011) "O'zbekiston mustaqillikka erishish ostonasida" $-\mathrm{T}$.: O'zbekiston, 2011.
14. Karimov I.A. (2015) "Ona yurtimiz baxtu iqboli va buyuk kelajagi yo"lida xizmat qilish - eng oliy saodatdir" -T.: O'zbekiston, 2015.

15. (2016) "The report" of the people creativity and cultural-spiritual works Republic scientificmethodical center, $2016 \mathrm{y}$. 